\title{
Fractured Bodies and Diseased Societies: Medicalizing Quebec in Cité Libre
}

In 1962, Pierre Trudeau alerted the readers of Cité libre, Quebec’s small but influential political and cultural journal, to the dangers of thinking of the nation as "une réalité 'biologique’” (5). Railing against both clerico-conservative nationalists and their new sovereigntist counterparts, who were oriented toward socialism, he warns against blindly accepting their medicalized rhetoric of the body politic. Trudeau's admonitions about the insidiousness of biological tropes in Quebec's nationalist circles notwithstanding, he diagnoses French Canada — within the same article_-as anaemic, sclerotic, and retarded (12). If one things is clear from the finger pointing and Trudeau's inflammatory diagnoses, it is that the rhetoric of the body is very much a part—albeit a contested one_-of political discourse in Quebec.

The idea of couching problems within society in corporeal and even clinical language is a longstanding and effective rhetorical strategy. The body used in service of ideology signifies with tremendous persuasive power, for as Sandy Petrey explains, the "task of ideology is to confuse nature and history until the difference between them is erased from collective consciousness and the conventional effects of conventional procedures appear to be the material effects of a physical cause” $(1998,180)$. What trope could be better at blurring the line between nature and history than that of the body? Everyone has a body and, to varying degrees, understands its processes. To associate the body and specifically its failings with the nation’s problems, contend literary and cultural critics David Caron, Sander Gilman (1985), and Terrence Bowers, transforms the often intangible, theoretical, and ideological matters that constitute the political into identifiable and comprehensible problems that demand sensible and immediate solutions that should be apparent to all. 
In Cité libre, medical metaphors illustrate problems as diverse as clericalism and nuclear proliferation. They also foster, via their increasing specificity, frequency, and their implied virulence, a vision of a "sickening" Quebec that seems to be at odds with the history of social and political change within the province. To read these individual tropes as parts of a larger national allegory, one predicated on the diagnosis of a collective inferiority complex, however, changes the image of Quebec that is posited, for the metaphors can be seen as a part of a larger performative allegory of cure. These contradictory ways of reading the medical references, while emblematic of the different historiographic trends in the province (a controversy discussed in the pages of Cité libre), also highlight the broader conflicts and ambiguities that characterize the medicalized discourse of nationhood in Quebec and point to the inadequacies of the body politic as a supposedly unambiguous, even "objective” trope of the nation.

\section{Cite libre and Social Ills: An Overview}

While political journals with a small circulation limited to an intellectual elite rarely have a sweeping effect on a nation's self perception, Cité libre's mainstream influence was considerable. Michael Behiels notes that, although the journal generally printed fewer than 1500 copies, its editors and contributors carried its messages to "the airwaves and television screens of Radio Canada as well as to the pages of Le Devoir and other Quebec dailies” (72) and therefore extended its reach. The journal's mission was to provoke debate on the many problems and challenges facing Quebec and, to a lesser extent, Canada. The state of Quebec as a nation, crises in the province's various social institutions, and its political leadership were among the favourite topics discussed in its pages. Scarcely an issue was published, however, without some reference 
to a social or political problem described in clinical terms. The list of conditions which portray Quebec and its issues reads like the index to a medical textbook: cancer (Pellerin 1966, 7), anemia (Morin 1964, 3), infection (Le Moyne 1955, 7), blindness (Tremblay 1961, 7), sclerosis (Charbonneau 1957, 36), atrophy (Cité libre 1958, 35), sterility (Dufresne 1961, 25), leprosy (Hébert 1960, 24), allergies (Dion 1961, 5), plague (Parenteau 1960,17), asphyxia (Trudeau 1961, 5), germs (Guay 1961, 22), contagion (Cook 1965,11), symptoms (Cormier 1950, 29), paralysis (Vadeboncoeur 1953, 21), wounds (Vadeboncoeur 1952, 27), fever (Lagueux 1965, 22), anatomy (Dion 1961, 5), putrefaction (Dion 1961, 5), and diagnosis (G.C. 1961, 8) are just some of the medical notions evoked. The truly comprehensive range of ailments that characterizes Quebec’s problems is paralleled by the variety of ways contributors employ medical language. Some, such as Pierre Godin in his 1962 article “La ‘peste’ nucléaire,” deploy it as a fully developed metaphor (43). Others, notably Jacques Hébert in "Nous sommes tous des lépreux,” only briefly mention a well-known disease (1960, 24).

The rationale for considering the incidence and the nature of this group of metaphors stems from the prominent role Cité libre played not just on the obviously political stage, but also in the subtler discursive process by which French Canadians in Quebec (particularly young, educated, liberals) collectively conceived of the nation and propagated a message about what they believed Quebec and its people to be. As Homi Bhabha and Richard Handler have argued, societies collectively shape themselves to the model(s) of nationhood articulated in their dominant cultural discourses and also intervene to form these discourses according to their own vision of the nation. In so doing, they alter them from strictly prescriptive or doctrinal articulations of nationhood to ones that are also representational of shared beliefs, attitudes, and 
practices. Cité libre, both in general and with its medical rhetoric, participated in this two-way process of both shaping and reflecting attitudes and events.

André Carrier and Daniel Latouche studied the journal’s personalist ideological inflection, as influenced by the French journal Esprit, Emmanuel Mounier, and the secular movements of young Catholics, which had gained ground in Quebec prior to the journal's publication. In the same vein, Ivan Carel, André Bélanger, Léon Dion (1993), and Andrée Fortin (among others) have considered the journal's intellectual heritage, but have also framed it as a launch pad for Quebec's emerging secular intelligentsia. ${ }^{1}$ E.-Martin Meunier and Jean-Philippe Warren examined its place in nationalist debates by analyzing the shift toward nationalism by some contributors from the original shared belief in social equality that drew them to Cité libre. Even Fortin's reminder that journals like Cité libre came to represent the opinions of a group which up to the journal's appearance felt excluded from society's discourses attests to the dual nature of Cité libre's intervention on the national stage (8-9).

The two-fold nature of Cité libre's participation in Quebec's debates about nationhood is also clearly represented in its use of medical discourse, which paradoxically posits the nation as being just as sick as it had ever been, but also in the process of recovery. Traditional nationalists like Lionel Groulx, who emphasized the survival of the "race" in their writings about the nation, drew on naturalist tendencies and thus called upon rhetoric heavily inflected with eugenic overtones and medical tropes. ${ }^{2}$ In using similar tropes, Cité libre fell into an established rhetorical pattern concerning the poor "health" of the nation. The journal's intervention in the medicalized discourse of nationhood, while on the surface no different than Groulx's discussions of society's ills, is perhaps best demonstrated by the very scholars who study it. André Bélanger, for instance, writes of Cité libre’s goal of bringing about a "réhabilitation idéologique et morale" 
(1977, 96, emphasis added) and Daniel Latouche and Andrée Fortin comment on its diagnostic function, albeit without ever acknowledging the medical tropes. If the clinical language used to describe Quebec is no less virulent than it was before, why is it that historians perceive Cité libre to be curative? Do these critical observations stem from a more or less unconscious (but admittedly widespread) appropriation of medical rhetoric and the idea of the body politic to describe styles of critique in political writing or do the critics' observations reflect actual shifts in Cité libre's positing of Quebec as a body politic and its view of itself as a form of therapy for the nation?

Before further delving into an analysis of the clinical rhetoric in Cité libre, I would like to outline some of the criteria used in the identification and analysis of the medical tropes contained therein. First, allow me to acknowledge that tracking rhetorical trends in a publication that spans sixteen years, which has both regular and occasional contributors, and shows a relatively light editorial hand with regard to articulating a cohesive message is an undertaking that flirts with generalization. Likewise, the very nature of rhetorical analysis makes it a subjective undertaking. For the purposes of this study, however, a few guidelines serve to establish a bank of tropes to be examined. I label trope any metaphorical or otherwise rhetorical invocation of the body, its processes, and/or its pathological states as well as references to medical care and its outcomes. The reference need not be developed to the point of constituting a structuring metaphor for the article as a whole, but only references in which it is clear that the subject at hand is being discussed in clinical terms are included. Brief mentions of a specific disease that convey clear medicalization are granted equal weight as fully developed metaphors. Likewise, both mental and physical conditions are considered, although tropes of physical illness are much more common in the publication itself. ${ }^{3}$ 
Since much of the analysis that follows involves delineating semantic differences between tropes, I employ a simple system of classification. Negative or ailment-oriented tropes are tallied by counting mentions of specific diseases or conditions (i.e. cancer, paralysis) or medical processes that are the likely result of a diagnosis (i.e. amputation being the result of gangrene). This category also includes vague references to sickness (designated by the French terms mal, maux, and maladie), symptoms (i.e. fever, atrophy), and references to diagnosis. Positive or treatment-oriented tropes are those that mention cures, treatments, remedies, good health, or vitality. Only a few medical references, particularly those referring to the life cycle, can be described as neutral in tone and are thus excluded from the count because the clinical context is not assured.

The tropes in question are all drawn from the feature articles and editorials of both the original ten-year run and the six-year long "nouvelle série”. The choice of the features owes to the fact that these articles tend to be longer and more substantive stand-alone essays than the page or paragraph-length observations of the other sections. Most often, the features and editorials concern themselves with political, economic, and social subjects, although they occasionally deal with cultural and artistic matters. (Most discussions of culture and the arts can be found in a special section entitled "Chronique du temps perdu”.) In so far as discussions of these latter issues, including literature, take place in the features, they are considered for this study.

An initial survey of the publication reveals an appropriation of clinical language that strongly favours metaphors sickness. Negative or ailment-oriented metaphors outnumber those focused on more positive aspects of the medical experience, such as health, rehabilitation, or treatment, by a ratio of approximately four to one (104 to 24). This decidedly pessimistic, if not 
altogether morbid, approach to medicalized political discourse insinuates that Quebec is, at the least, suffering, and at the worst, fatally threatened by its myriad illnesses and diseases. Such a conclusion puts the journal in line with other genres in Quebec, namely history and literature, which use medical tropes to cultivate the impression of a pathological society. Maurice Arguin subtitled his 1991 literary history of the novel in Quebec Symptômes du colonialisme et signes de libération, which implies that the literature of a still “colonial” Quebec is the sign of the nation’s disease. ${ }^{4}$ Similarly, Jane Moss notes that sickness, a prominent theme in Quebecois novels, often translates into highly pessimistic prognoses for the nation allegorized by the ailing characters. To read these metaphors as signs of an ailing Quebec is therefore an interpretive strategy with considerable precedent. ${ }^{5}$

In many explicitly political discourses, however, troubling diagnoses are almost always framed as steps to a cure, not an end in and of themselves. ${ }^{6}$ The prognosis of the clearly identified sick political or social entity "is always, in principle, optimistic. Society, by definition, never catches a fatal disease” (Sontag 1978, 76). As such, the diagnosticians reserve the possibility for a cure that they, presumably, can supply if only given the power to do so. Cité libre's appropriation of medical metaphors can be taken, on the whole, as a good example of this kind of political discourse, but it never the less presents certain divergences from the key notions of, first, pointing out the problems with the old guard, and second, cautious confidence when it comes to society’s prognosis. Should one see illness and disease metaphors as a way to communicate vehemence against an established political order, it stands to reason that medicalized rhetoric would be at its peak when dissatisfaction is greatest because the metaphors would suggest the severity of the problem and the need for a solution. Cité libre, at least upon 
first glance, strays from this logic, for both the incidence and severity of the metaphors increases as the potential for (and execution of) political and social reform sets in.

From 1950 to 1959, the years during which the Union Nationale controlled the National Assembly and maintained policies vehemently opposed by the Citélibristes, the medical tropes dotting the pages of the liberal publication are sparser than at any other point in the journal's history (an average of roughly six tropes per year). Admittedly, at this time the journal published on a very irregular schedule rather than operating as a more or less monthly magazine, so there was decidedly less content to reflect any one thematic or rhetorical preoccupation. During this ten-year period 56 medical tropes dot the pages of Cité libre. From 1960 to the end of the journal's run in 1966, a period that corresponds to the Liberal governments of Jean Lesage and sees the political start of the Quiet Revolution, by contrast, there are 72 tropes, 38 of which come in the three years immediately following the defeat of the Union Nationale. Given that Cité libre spent the first ten years of its existence lambasting the Duplessis government, the clergy, their policies, and their infiltration of Quebec's social institutions it stands to reason that this period, and not that of the long-awaited ascension of the Liberals to power, would be the one marked by the fervent language of pathology. Why then is the rhetoric of disease most prominent at precisely the moment when the time of transformation is at hand? I venture that the answer to this question rests not so much with the dearth or paucity of medical tropes that comes from tallying metaphors or even their individual connotations, but rather with their function in a slowly developing diagnostic narrative, for individual tropes took on new and significant inflections leading up to and during the 1960s.

By looking at the medico-national allegory formed by the isolated tropes, one can discern three distinct phases in the evolution of medical discourse in Cité libre: the first extends from 
1950 to 1954, the second from 1955 to 1959, and the third from 1960 to the end of the journal's run in $1966 .^{7}$ Considered together, these three parts of the larger allegory and the changes they represent contradict the notion of the sickening Quebec suggested by the patterns and trends of the metaphors.

\section{Charting the Evolution of a National Ill}

In the early run of the publication (1950-1954), many of the articles that used medical tropes took aim at French Canadians as a people or as a nation. Francophone Quebecois were criticized for being politically complacent, unworried by the undue influence accorded to their clergy, excessively cautious, and immature as a nation. The title of an article by Pierre Vadeboncoeur, "Critique de notre psychologie de l'action," (November 1953) acts as just this kind of sweeping indictment. In his text, which is first and foremost a psychological profile of a less-than-mentally-healthy population, Vadeboncoeur chides French Canadians for their political apathy. Despite the psychological implications of the title, the author's use of medical tropes centres on physical impairments. He denounces nationalism as a kind of false panacea with dangerous side effects: "Quelle est cette assemblée de prudents détenant en grande partie hors d’usage sur le peuple, une sorte de représentation comme légitime du populaire? Représentation dont la conséquence est claire: elle paralyse le peuple” $(1953,21)$. Recognizing the way in which traditional nationalism, as seen in the current incarnation of the National Aseembly, corrupts by stifling the impetus for change, Vadeboncoeur turns to the idea of paralysis to express the stagnation that he characterizes as firmly entrenched within the national psyche. Another of Vadeboncoeur's articles, "Pour une dynamique de notre culture," allows him to rail 
against the torpor of French-Canadian society owing to its seeming veneration of its own failings: “Nous languissons d'une maladie mortelle du caractère” (1952, 19).

François Hertel, (in)famous for his voluntary exile to France in protest against the stifling cultural climate in Quebec, also takes issue with the psychological state of French Canadians in "Les évolutions de la mentalité au Canada français”. As he critiques Quebec’s self-perpetuating mentality of collective immaturity, he likens Quebec to a late-blooming child only finally entering a quasi-precocious adolescence and looks for other symptoms of this delayed development. He finds them in the national literature, which he describes as "quelques oeuvres exsangues,” which are "sans inspiration et sans vie” (1954, 49). Both Vadeboncoeur and Hertel provocatively translate what they perceive as psychological shortcomings on a national scale into physical conditions—paralysis, bloodlessness, and lifelessness—which represent extreme bodily failings. ${ }^{8}$

While the concentration of medical tropes in these early years is decidedly less virulent or pathologically specific than it is later on, the tropes converge around several themes. First, they connote stagnation, inertia, or a generalized lack of vitality. Neither contagions nor diseases per say, the conditions affecting French Canadians and their national mentality never the less make clear the dire situation facing the nation. In light of the conservative, even reactionary, government in Quebec at the time, these metaphors make a great deal of sense. Second, the pathological references typically come in the context of an article whose title could be crudely reduced to "What's wrong with French Canadians?" Third, the frequent pairing of positive and negative tropes in a single article, for instance in "Histoire des collégiens qui ont aujourd'hui trente an" by Gérard Pelletier (1960), suggests that whatever ails the nation (be it a wound or paralysis) is remediable. ${ }^{9}$ That the medical connotations of the individual metaphors belie this 
pairing is perhaps the first hint that the tropes are creating larger ambiguities and discrepancies in the body politic that is Quebec.

Between 1955 and 1959 (although with some overlap in 1954 and some echoes toward the end of Cité libre's run) the metaphorical and allegorical discourses continue to present differing narratives of the nation's figurative illness. The tropes, while not plentiful, are richer than they were in the early years. This new turn reflects a greater preoccupation with the nation (both as the abstract entity encompassed by the idea of nationhood and as a more concrete nation state) and how French Canadians in Quebec saw themselves as part of it. ${ }^{10}$ The discourse of pathology accordingly focuses on the clerical leaders, the Union Nationale political machine, and the institutional influence they wielded in articulating and disseminating a paradigm of "official" nationhood for Quebec. Once identified as problems—diagnosed—-these traditional leaders and their policies (and not the people or the nation itself) are denounced as the cause of Quebec's various national ills. The second major shift in medical rhetoric, while still concerned with the people on the whole, involves the identification of an overt, and frequently pathologized, discourse of victimhood or inferiority.

In “L’atmosphère religieuse au Canada Français," one of many anti-clerical articles, Jean Le Moyne pronounces the nation riddled with an excess of Catholic guilt. Unlike earlier medical metaphors in the tradition of “what's wrong with French Canadians?” Le Moyne identifies the source of the pathological guilt, the clergy, as one would trace the aetiology of a disease. He accuses the nation of having contracted "la contagion de la culpabilité" $(1955,12)$ from a church “infecte de culpabilité jusqu’au sources de l'être” (7). The pervasiveness of this inculcated guilt has initiated a "paralysie pour la belle jeunesse," which consequently arrests the normal impetus for change brought to the political scene by new generations (7). Le Moyne also teases out the 
specific ways in which the Church infects the nation: "Notre morale est naïve comme un symptôme: la hantise sexuelle et l'obsession compensatrice de l'autorité que nous rencontrons ici nous situent en pleine psychopathologie. Nous ne mourons pas tous, mais nous sommes tous frappés. Des malades paissent des malades. Des victimes engendrent des victims” (9). According to Le Moyne, the priestly obsession with repressing sexuality has created a veritable psychological ailment, which has crept over into the physical realm. In saying that everyone is affected by the problem that he alternately terms an infection (7), a contamination (7), a contagion (12), a sickness (12), and an amputating force (13), he retains the kind of blanket statements about French-Canadian society typical of earlier articles. Still, he pushes his readers to recognize that the fault for the widespread problems can be traced back to the "contaminating" Church and the process by which the top-down values of Quebec's official nationhood had been adopted and spread. In short, Le Moyne’s diagnosis shows greater specificity than earlier examples.

Léon Dion takes a similarly accusatory stance toward nationalists, namely the emerging generation of neo-nationalist historians, in "Le nationalisme pessimiste: Sa source, sa significaiton, sa validité”. Dion's argument is that the vision of nationhood articulated in their histories has become so pessimistic that even positive signs are mistaken for problems and indications of national failing: “La relative prospérité économique et l’essor culturel lui-même représentent, du point de vue néo-nationaliste, des symptômes certains de déperdition du caratère canadien-français” (1957, 7). To cast economic success and cultural ascendancy as symptoms of a disease affecting the very core of French-Canadian being confuses signs of health and symptoms of disease. To write (and by extension teach) Quebec's history as a series of defensive responses to any change, even those of a positive nature, consequently hinders the development 
of the nation. Critiquing this kind of negative orientation, Dion falls just short of categorizing Quebec as a hypochondriacal society, its leaders the most insistent of the malades imaginaires. In calling attention to the nationalist use of "fake” symptoms, Dion begins to place these intentionally alarming tropes into a larger narrative of a (this time legitimate) illness:

Le tragique de la position néo-nationaliste résulte d'une incapacité de découvrir une alternative au dilemme insoluble dans lequel ils s'enferment: ou bien un national complet dans le sens de la perspective séculière ou bien l'état d’infériorité permanente sinon la disparition éventuelle du groupe ethnique canadien-français. $(1957,14)$

Neo-nationalists, explains Dion, frame the debate about French-Canadian identity in such a way that anything short of a radical redefinition of the nation—sovereignty for Quebec — relegates French Canadians to a perpetual state of inferiority. Given that the neo-nationalist ideal of a sovereign Quebec was at the time (and arguably still is) out of reach, the de facto state of affairs in Quebec is to see the nation as suffering from an inferiority complex, a kind of coping mechanism, that keeps the death of the nation at bay. It is thus that Quebec's national hypochondria becomes a veritable psychological illness, which according to neo-nationalist rhetoric, sustains the nation, albeit in a weakened state. The pathology of the inferiority complex, no matter how contested or arbitrary it may be, subsequently becomes (at least according to those Dion critiques) the practical way for French Canadians to survive. The myth of French-Canadian fatal inferiority, which could only end in assimilation, furthermore, is a prominent theme of neonationalist rhetoric, for it provides the impetus of a credible threat to French-Canadian society (the attention-grabbing diagnosis) within a larger nation-state. Dion is none the less quick to point out that this kind of fatalism can, contrary to nationalist rhetoric of new beginnings, only perpetuate stagnation: 
Partout [on trouve] des problèmes "fondamentaux" et des secteurs de "crise." Rien d'anormal à ce qu'il en soit de même pour le groupe canadien-français. L'anormal serait que celui-ci voit dans la conquête de 1760 une cause irrémédiable de sa situation et que croyant réaliser l'inutilité de toute recherche de solutions, il attende [sic] la mort. (18)

The inferiority complex becomes not a spur to action and reform, as neo-nationalists had hoped, but rather a terminal prognosis that has been hanging over Quebec for nearly 200 years.

The pathological nature of the inferiority complex becomes clearer in Gérard Pelletier's “Réflexions sur l’état de siege (de Jean Desprez à M. Duplessis)” and sociologist Marcel Rioux’s “Idéologie et crise de conscience du Canada français”. The premise of these articles is to attack those who fabricate stories of victimization so as to position themselves as the triumphant defenders of a cause. Both contributors undermine the familiar nationalist story of French Canadians as the long-suffering victims by turning classic tropes of inferiority_-bodily difference and pathology_back upon the inferiority complex itself. Pelletier takes aim at the socalled siege mentality or the ethos of inferiority that French Canadians and their traditional leaders have cultivated. He argues that French Canadians, following influential leaders like Duplessis, have so inured themselves of their perpetual victimhood that they can no longer see that it is not their deficiencies vis-à-vis English Canadians that undermine them, but rather their clinging to a post-Conquest siege mentality:

Nous ne sommes, en gros, ni plus bêtes ni plus intelligents, ni plus malades ni plus sains que les autres groupes humains de notre entourage. Il faut toutefois admettre que nous ne sommes guères rassurés sur notre sort collectif et que de là vient une grande part de notre mal. $(1957,34)$

In moving from the idea of advancement being a sign of some national ill to the notion that Quebec’s persistent embrace of its inferiority constitutes a pathology (un mal) in and of itself, Pelletier at once rejects the idea of a terminally sick nation and paradoxically enshrines a new 
diagnosis, one that is meant to be a wake-up call for a treatable condition rather than a mere label.

Rioux goes even further than Pelletier does. Instead of likening the complex to a vague illness or a pain, he provocatively compares the inculcated French-Canadian psychological ailment to missing limbs and leprosy:

Si l'on veut comparer l'état du minoritaire à celui de l'unijambiste chez qui ce manque d'être obnubile toute la personnalité au point qu'il envisage tout sous l'aspect de l'unijambisme, peut-on dire que le Canadien se pense ainsi? On se pose la question au sujet de l'ensemble des C.F. et non pas seulement à propos des professionnels du complexe d'infériorité, à ceux qui en sont maladivement les victimes, qui le propagent et le sèment comme la lèpre. $(1955,21)$

Rioux, like Le Moyne, distinguishes between the "professional” disseminators of the inferiority complex, the traditional and neo-nationalists, and its victims who cannot help but spread it to others. Separating the average "sick" person from the vocal proponents of the inferiority complex, those who knowingly infect others, allows Rioux to salvage an overall healthy diagnosis for the population.

Expressing notions of inferiority in clinical language stems from "the idea of the pathological [as] a central marker of difference” (Gilman 1985, 23). Quebec’s own medical historians and physicians have long since suggested a link between perceived inferiority and expressions of biological difference or abnormality. Doctors, Denyse Baillargeon notes, saw in the still alarming early-twentieth-century infant-mortality rates a reflection of "les préoccupations d’une société incertaine de son statut, de son avenir et de sa capacité à relever les défis de la 'modernité’” (2002, 121). Baillargeon’s insistence on the link between the alarming public health statistic and French-Canadian anxiety about Quebec’s place in the modern world reflects Raoul Masson's earlier concern about feelings of cultural inferiority and their relation to abysmal public health figures. Masson, a pioneer of paediatrics in French Canada, is never the 
less more direct than Baillargeon in his assessment of the relationship between perceived inferiority and medicalization: "Quoique toujours il soit pénible de reconnaître un tort ou d'accuser une infériorité, il faut avoir le courage d'avouer le mal que l’on veut guérir” (1925, 6). Masson's openness about the lamentable state of French-Canadian health decades earlier echoes in Cité libre's overall approach to the perception of social ills of all kinds (including inferiority) and their rendering as attention-getting disease.

By acknowledging the problem of the inferiority complex and drawing attention to it, the contributors show themselves to be "courageous". ${ }^{11}$ Still, by insisting upon Quebec's problematic complex in an influential publication like Cité libre and doing so using a rhetoric of pathology so similar to the metaphors of illness that impugned the French-Canadian population during the early 1950s, one can argue that the journal, in spite of its stated aims, further ensconces the idea of Quebec's victimhood via its use of pathological metaphors. The challenge for the Citélibristes therefore becomes one of separating their own earlier use of illness metaphors from that of the nationalists and again from their diagnosis of the inferiority complex, which is the basis of the larger allegory.

By 1960, this challenge is met by further deflecting the rhetoric of pathology onto problems instead of onto people (be they the nation or its leaders) and by intensifying the focus on diagnosis and treatment within the larger frame of medical rhetoric. In the final years of publication, metaphors of disease are no longer used exclusively to speak about the state of the nation, its people, or even its leaders, but are increasingly employed to identify and address very specific problems such as racism (Hébert 1960), nuclear proliferation (Godin 1962), and unemployment (Parenteau1960). While many of these issues affect Quebec, they are not necessarily problems with the province itself, nor with Quebec's status as a nation. The language 
used to discuss these matters also reflects a much more targeted approach. Nearly half (28 of the 72) of the total medical metaphors in these years refer to specific diseases, symptoms, or pathological states, such as cancer, fever, congenital malformations, and atrophy. This combination of distinct socio-political issues described in exacting medical terminology suggests that the contributors were more thoroughly examining their society than they had before, or were at least doing so in a way that generated more pointed critiques than in the past. In the case of some diagnoses, such as infections, the cure is also implied.

J.-G. Guay in "Écho à 'Urgence d'une gauche nationale’, ” for instance, scrutinizes traditional nationalism, not just as an idea and an opposing ideology, but also in its continual thwarting of an effective left-wing political movement to rival the Union Nationale:

Dans cette province comme ailleurs, le microbe nationaliste reprend vie périodiquement dans son bouillon de culture qui est la crise économique. Il s'est agité et est devenu virulent dans les années '30 et il recommence actuellement à proliférer avec les malaises économiques croissants. Et dans les cas aigus le microbe nationaliste produit inévitablement dans le corps social le délire du fascisme sous une forme ou sous une autre. $(1961,22)$

Guay's illustration of the dangers of nationalism highlights the effects of this socio-political movement on the proper functioning of the body and the mind. Characterizing nationalism as bacteria that cause delirium, Guay's explanation is rife with the language of medicine (les cas aigus, le corps, la virulence, les malaises) and bacteriology (le microbe, le bouillon de culture). He delves into the aetiology of the disease (le microbe), the conditions leading to flare ups (la crise économique,) and the nature of these acute episodes (le délire du fascisme).

The medical references, while rarely as developed as the ones that Guay puts forth, never the less continue to combine particular socio-political issues with medical language, and often with specific diagnoses. Jacques-Yves Morin’s article on senate reform, “Un nouveau rôle pour un sénat moribond" accuses the Canadian economy of suffering from anaemia and the process 
for constitutional change of being “paralysé au depart” (1964, 11). Roland Parenteau misleadingly titles his article on the impact of unemployment "La peste noire du XXe siècle,” but goes on to argue that "Le chômage... c'est un peu comme certaines maladies contagieuses de l’enfance” (1960, 17). Jacques Tremblay gets creative in “Je voudrais parler à un homme,” a rather general overview of Quebecois society reminiscent of early Cité libre, with the subheading for his section on religion reading “Diagnostic: Cléricalite (comme on dit appendicite)” (1961, 5). An article by Jean Pellerin and André Rossinger, which analyzes the reasons for the defeat of the Lesage Liberals is simply titled “Autopsie du 5 juin”(1966). While often more cursory in their appropriation of medical metaphors in the later years, contributors never the less mustered them to more pointed and effective use.

The surge of metaphors, specifically those of named diseases, likely owes to a combination of changes within Cité libre and to the larger current of self-examination and reform in 1960s Quebec. André Bélanger maintains that the 1960s initiated a new style of critique in Cité libre, one that focused on policy rather than on the style of governing. He contends that the new policy initiatives following years of complacency and status quo governing under the Union Nationale, one of the previously identified national ills, finally gave the Citélibristes policies to consider and critique (96). Hence even without changing the nature of the rhetoric, the medical metaphors are now evaluating the merits of the "treatments." The increased attention to cure is directly represented in the metaphors. From 1963 to 1965, there are eight explicit references to treatments, remedies, and cures, whereas the entire decade prior to Lesage taking office yields ten such tropes. $^{12}$

If treatment is now possible, it is because diagnoses had paved the way. Of the nine explicit references to le diagnostic or diagnostiquer that occur in the run of Cité libre, six of 
them arise between 1960 and 1966, five in either 1961 or 1962. This shift toward diagnosis (coupled with the specific diagnoses) occurs at the same time as governments launched formal investigative commissions into some of the biggest and most troubled social institutions in Quebec. The Parent Commission on education (initiated by the provincial government in 1961) lead to the secularization of schools and the federal Royal Commission on Bilingualism and Biculturalism (begun in 1963 and with a preliminary report being issued in 1965) forced Quebec to look critically at itself as a society, and specifically its schools, culture, and economy. The emphasis on diagnosis and treatment, and not simply the realization that problems are present, suggests that the core issue in 1960s Quebec is not the further sickening of the nation, as the overall proliferation and intensification of medical metaphors implies, but rather precisely identifying, explaining, and treating existing problems. ${ }^{13}$

The journal's recognition of its own increasingly diagnostic orientation and function within Quebec came in March of 1961, when Cité libre published an anonymous (the author is identified only by the initials G. C.) letter:

On éprouve un malaise: vite on accuse la glande qu'on sait la moins solide, la plus vulnérable, car si c'était un autre—ça pourrait être vraiment grave. Et il ne faut pas ... que ce soit vraiment grave, grave au delà des risques qu'on peut raisonnablement assumer. Ainsi le diagnostic est-il conditionné par le courage (ou le manque de courage) du médecin.... Intellectuels, vous êtes les médecins de cette nation. (7-8, emphasis in original)

G. C. warns the public intellectuals of Cité libre to be thorough in their diagnoses so that the real problems of the nation (unemployment, the dominance of foreign capital, immigration policy, health care, etc...) do not go unnoticed and untreated for the sake of indulging the journal's pet diagnoses of clericalism and nationalism. By chiding those whom he identifies as the nation's doctors, the author recognizes the Citélibristes as arbiters of a significant portion of the public agenda, all the while further investing them with that power. Printing the letter consequently 
becomes a public acceptance of the diagnostic and, by extension, curative roles bestowed on the publication.

One of the prime indications that Cité libre had fully and consciously assumed an interventionist function not only within society comes in Yerri Kempf's “Comment peut-on être Canadien français?” Kempf, an immigrant to Montreal and long-time contributor (although rarely to the features articles), cites Freud's theory that trauma must be acknowledged before it can be overcome and argues that Quebec's youth is poised to acknowledge their collective inferiority complex as just such a trauma:

Cette prise de conscience qui libère la Psyché québécoise des effets paralysants du passé, permet une réévaluation de nos possibilités et nous projette fougueusement en avant. Il ne s'agit, ni plus ni moins, d'une mutation du complexe d'infériorité qui motive en profondeur ce changement d'attitude. $(1965,25)$

Kempf's position is nearly identical to that espoused by the likes of Rioux and Pelletier, and more pointedly, to the language that physicians like Masson had used earlier in the century to talk about Quebec's actual public health crises, but he pushes the idea further. He contends that the paralysis of the past not only can be, but also is being reversed by the acute change in attitude in Quebec. ${ }^{14}$ The simple act of looking critically at one’s society and one’s role therein, something Kempf attests to doing through his article, is deemed the single most important step in the nation's evolution away from unhealthy notions of victimhood and disease. The discussion of the problem taking place in Kempf's article—and the earlier examination of the issue — then become, albeit retroactively, cures in and of themselves. Every other diagnosis can similarly be recast as part of a larger treatment plan for the nation, "a cure premised on the accuracy of ... diagnosis," (Caron 2001, 14) but which only declares itself so at the end of the narrative.

If Cité libre had always seen itself as a diagnostic, if not curative, entity within Quebec’s political arena, its direct reiteration of these views in the waning years of the publication begs the 
question of why such a reaffirmation is necessary. The most obvious answer is that their diagnostic and curative abilities were being doubted, and one of the biggest sources of misgivings in this regard was the neo-nationalist journal Parti pris. In both March and May 1964, the editorial team of the rival publication accused the obliquely identified Citélibristes of misdiagnosing Quebec’s social ills: “Et même des hommes qui se prétendent encore honnêtes et sérieux, qui ont fait des grèves célèbres et diffusé des idées de liberté et de justice sociale, persistent aujourd'hui à méconnaître la nature profonde des malaises de notre société” (Parti pris 1964, 17). In several other articles, notably the March 1964 editorial and a piece by Jean-Marc Piotte in September of the same year, the same critique of the diagnostic abilities and the resultant misguided attempts to impose social cures is levelled against the 14 year-old journal. Faced with such accusations, it would be natural for the contributors at Cité libre to defend their enterprise and the validity of their conclusions. Kempf's comments, without necessarily endorsing the neo-nationalist agenda, reclaim the spirit of questioning brought to the political scene by the sovereigntist writers as part of the larger movement initiated by Cité libre almost a generation earlier. In essence, he takes the accusations of the group that frequently wrote about the collective inferiority of French Canadians and which justified its existence as an answer to a liberal bourgeois journal that was incapable of seeing the true nature of Quebec's problems as proof that the therapy for the "paralysis of the past" was working. The sort of psychoanalytic talking cure that Kempf envisioned is therefore fulfilled in the allegory that Cité libre as a whole represents, and perhaps even more shrewdly, the critiques of the shortsighted diagnoses (the metaphors of disease) become part of this cure.

\section{Side Effects: Medical Rhetoric and Nationhood in Quebec}


Kempf's timely and unusual intervention in Cité libre's illness narrative allows Quebec's prognosis to remain optimistic and the diagnosis-laden writing of the journal accurate (and thus curative), even in the face of harsh criticism. As Kempf clarifies the larger allegory to rehabilitate both his own journal's diagnosis-laden history and the criticisms levelled by the sovereigntists, it is never the less quite easy to see how this therapeutic intervention can be overlooked and the inferiority complex read as just another (potentially inaccurate) diagnosis in a publication already teeming with them. Failing to make the distinction between the trope being part of the allegory and a metaphor unto itself, something more likely due to the serialized format of the journal, simply feeds into the idea of a sickening nation that has not been helped by previous attempts to establish and remedy its ills.

A second, more fundamental, problem with the use of medical rhetoric in shaping national discourse, and consequently in shaping the nation itself, springs from Quebec's somewhat unusual situation as a nation (with disputed sovereigntist aims) within a nation (state). If the nation is represented by the ailing body in medicalized political discourse, one is subsequently forced to determine which nation corresponds to which body, if indeed a second body is even introduced into the rhetoric. The particularly inflammatory article, "La Nouvelle trahison des clercs," by Trudeau in the issue dedicated to separatism, draws attention to this very problem. In seeking to explain to French Canadians why their sovereigntist projects are ill advised Trudeau proffers: "La nation canadienne-française est trop animiée culturellement, trop dépourvue économiquement, trop attardée intellectuellement, trop sclérosée spirituellement” $(1962,12)$ to survive as a sovereign state. In labelling French Canada (namely Quebec) with such medically provocative terms, Trudeau uses the nation not only as a rhetorical body, but also 
depicts it as a body that is so profoundly marked by abnormality and pathology that it cannot thrive on its own.

The direly sick nation (state) in waiting Trudeau discusses survives, to extrapolate, because it is part of a larger, presumably healthy nation. Given Trudeau’s federalist stance, it is logical to surmise that he sees Canada’s vitality making up for Quebec’s bodily failings. According to his logic, Quebec's national pathologies are mitigated enough for them to pose no serious risk to either the larger Canadian nation state or the smaller nation within a nation. The impact of these diseases and conditions on the larger national body of Canada never the less go unnoticed by even those most attuned to the dynamic between the nations, be they nations in the more abstract sense of a people or recognized sub-national, political entities, such as provinces. French Canada’s paralysis in no way impedes Canada’s march, Quebec’s invasive cancers pose no metastatic risk, and its anaemia does not alter the blood count of the nation state that comprises it. It is thus that Quebec and its bodily rhetoric are always inscribing and creating a national illness for itself, albeit one that defines Quebec as a distinct (if still pathological) national body. At the same time, those who, like Trudeau, doubt the viability of an independent Quebec and favour federalism, also ignore the singularity and unity of the rhetorical body that makes their discourse of disease and pathology within the tradition of the body politic possible.

If Quebec's pathology is neither dismissed as being relatively benign to itself and the rest of Canada, nor recast as a spur to its vitality (as it is in a 1962 article by Jean Bouthillette in which he argues that Quebec's survival issues from its precarious state) the question of national consequences seems to be largely absent from the discourse that medicalizes and pathologizes the nation. ${ }^{15}$ Because these medical metaphors are never fully explained in relation to Quebec's complex nationhood, Quebec becomes a nation dependent on another for its health or, 
alternately, a sick nation in its own right. The curative implications of Cité libre's mediconational allegory are therefore circumscribed by the inability to reconcile Quebec's bodily selfrepresentations and the limits of bodies as rhetorical devices.

The rhetorical disjunction arising from the general notion of nation-as-body and Quebec's frequent and sometimes-contradictory medicalization of the nation within a nation unsettles the simplicity imputed to the rhetorical body. For the reader who looks beyond the shock value of metaphors of leprosy, plague, and anaemia that draw attention to problems beyond even the curative potential of the medico-national allegory, the real difficulty is that of the utility and function of the medical tropes themselves. The tropes in question, after all, are meant to simplify, illustrate and explain that which is harder to grasp as politicians and writers seek to persuade their audiences with the rhetoric of that which is an intrinsic part of their daily lives.

While arguably a specific case, Quebec’s difficulties with and challenges to the concept of the body politic point to more systemic problems with medico-national discourse. Specifically, the diseased nation within a nation leads, as Donna Haraway argues, "to the testing of the neutral parts of the analogy...to a searching for the limits of the metaphoric system and thus generates the anomalies important to paradigm change” (1976, 9, emphasis in original). It is only subsequent to the collapse of (or even evidence of faults within) the signifying system established by the trope that one truly seeks to understand the implications of the trope itself, and moreover, that which it explains.

In the case of Cité libre (and Quebec more generally) and its frequent use of medical rhetoric, the pathological analogies centring on the body politic, which may hold up when the 
nation is conceived of as a relatively unitary state with "simple" problems, begin to crumble when the analogy is stretched, most notably from discrete metaphors to a publication-long allegory, and both the medical and national implications of the specific trope are pushed to their logical ends. Quebec's unique national situation and its subtle and changing use of medical tropes, as evidenced in Cité libre, thus gives occasion to rethink how and why nations are likened to bodies, and to re-evaluate the critical approach to texts that employ the idea of the body politic. 


\section{References}

Arguin, Maurice. 1985. Le Roman québécois de 1944 à 1965: Symptômes du colonialisme et signes de libération. Québec : Centre de Recherche en Littérature Québécoise.

Baillargeon, Denyse. 2002. "Entre la "Revanche” et la "Veillée” des berceux: Les médecins québécois francophones, la mortalité infantile et la question nationale.” Canadian Bulletin of Medical History/Bulletin canadien d'histoire médicale 19: 113-37.

Beaudreau, Sylvie. 2002. "Déconstruire le rêve de nation: Lionel Groulx et la Révolution tranquille.” Revue d'histoire de l'Amérique française 56 (1): 29-61.

Behiels, Michael D. 1985. Prelude to Quebec's Quiet Revolution: Liberalism Versus NeoNationalism, 1945-1960. Kingston and Montreal: McGill-Queen’s Univeristy Press

Bélanger, André J. 1977. Ruptures et constantes: Quatre idéologies du Québec en éclatement: La Relève, La JEC, Cité libre, Parti pris. Montréal: Hurtubise.

Bélanger, Damien-Claude. 2008. “L’Antiaméricanisme et l'antimodernisme dans le discours de la droite intellectuelle du Canada, 1891-1945." Revue de l'histoire de l'Amérique française 61 (3-4): 501-530.

Bhabha, Homi K. 2004. The Location of Culture, $2^{\text {nd }}$ ed. New York: Routledge.

Bouthillette, Jean. 1962. “La mesure canadienne-française.” Cité libre, December, 10-13.

Bowers, Terrence N. 1995. "Tropes of Nationhood: Body, Body Politic, and Nation State in Fielding’s ‘Journal of a Voyage to Lisbon’.” ELH 62 (3): 575-602.

Carel, Ivan. 2003. “La Révolution tranquille en paradigms.” Bulletin d'histoire politique 12 (1): 201-210.

Caron, David. 2001. AIDS in French Culture: Social Ills, Literary Cures. Madison: University of Wisconsin Press.

Carrier, André. 1969. “L’Idéologie de la revue Cité libre.” Revue canadienne de science politique 1 (14): 414-428.

Charbonneau, Pierre. 1957. "Défense et illustration de la gauche.” Cité libre, November, 646.

Cité libre. 1958. “Notes sur le catholicisme d’un certain pays.” October, 35-42.

Cook, Ramsay. 1965. “L’Historien et le nationalisme: Le Cas de Michel Brunet.” Cité libre, 
January, 5-14.

—. 2005. Watching Quebec: Selected Essays. Kingston and Montreal: McGill-Queen’s University Press.

Cormier, Guy. 1950. "Petite méditation sur l'existence canadienne française." Cité libre, June, 22-36.

Dion, Léon. 1957. "Le Nationalisme pessimiste: sa source, sa signification, sa validité.” Cité libre, November, 3-18.

__. 1961. “De l’ancien au nouveau regime.” Cité libre, June-July, 3-15.

—.1993. Les intellectuels et le temps de Duplessis. Sainte-Foy, Presses de l’Université Laval.

Dufresne, Georges. 1961. “Marie-Claire Blais, visionnaire.” Cité libre, January, 24-5.

Fortin, Andrée. 1993. Passage de la modernité: Les intellectuels québécois et leurs revues. Sainte-Foy: Presses de l’Univisersité Laval.

G.C. 1961. "Lettre d’un nationaliste.” Cité libre, March, 6-8.

Gilman, Sander L. 1985. Difference and Pathology: Stereotypes of Sexuality, Race, and Madness. Ithaca: Cornell University Press.

— 1989. "Plague in Germany, 1939/1989: Cultural Images of Race, Space, and Disease." MLN 104 (5): 1142-1171.

Godin, Pierre. 1962. “La 'peste’ nucléaire.” Cité libre, January, 29.

Guay, J. G. 1961. “Écho à 'Urgence d’une gauche nationale’.” Cité libre, June-July, 18-23.

Handler, Richard. 1998. Nationalism and the Politics of Culture in Quebec. Madison: University of Wisconsin Press.

Haraway, Donna Jeanne. 1976. Crystals, Fabrics, and Fields: Metaphors of Organicism in Twentieth-Century Developmental Biology. New Haven: Yale University Press.

Hébert, Jacques. 1960. “Nous sommes tous de lépreux.” Cité libre, March 1960, 24-25.

Hertel, François. 1954. "Les Évolutions de la mentalité au Canada français.” Cité libre, October, 40-52.

Kempf, Yerri. 1965. “Comment peut-on être Canadien français?” Cité libre, March, 24-26. 
Lagueux, Maurice. 1963. "Réflexions sur l'enseignement de la philosophie au collégial.” Cité libre, April, 22-27.

Latouche, Daniel. 1970. “Anti-séparatisme et messianisme au Québec depuis 1960.” Revue Canadienne de science politique 3 (4): 559-578.

Lefebvre, André, and Jacques Tremblay. 1965. “Québec: Pour un politique du possible.” Cité libre, October, 6-15.

Le Moyne, Jean. 1955. “L’atmosphère religieuse au Canada français.” Cité libre, May, 1-14.

Letourneau, Jocelyn. 2000. Passer à l'avenir: Histoire, mémoire, identité dans le Québec d'aujourd'hui. Montreal: Boréal.

Maclure, Jocelyn. 2003. Quebec Identity: The Challenge of Pluralism. Kingston and Montreal: McGill-Queen’s University Press.

Marshall, Bill. 2000. Quebec National Cinema. Kingston and Montreal: McGill-Queen’s University Press.

Masson, Raoul. 1925. "La Mortalité infantile dans la province de Québec.” L’Union médicale du Canada 54 (1): 3-25.

Meunier, E.-Martin, and Jean-Philippe Warren. 1998. "De la question sociale à la question nationale: La Revue ‘Cité libre” (1950-1966)” Recherches sociographiques 39 (2-3): 291-316.

Morin, Jacques-Yves. 1964. “Un nouveau rôle pour un sénat moribond.” Cité libre, JuneJuly, 3-7.

Moss, Jane. 1985. “The Morbid World of the Quebec Novel.” Literature and Medicine 3: 152-166.

Parenteau, Roland. 1960. “La peste noire du XXe siècle.” Cité libre, August-September, 1718.

Parti pris. 1964. “La révolution, c’est le people.” Parti pris, May 1964, 2-10.

Pellerin, Jean. 1964. "Les USA achètent le Canada avec notre propre argent.” Cité libre, June-July, 8-20.

——. 1966. "Eric Kierans: Zéro de conduite.” Cité libre, July-August, 7-11.

Pellerin, Jean, and André Rossinger. 1966. “Autopsie du 5 juin.” Cité libre, July-August, 5-9.

Pelletier, Gérard. 1950. "Histoire des collégiens qui ont aujourd’hui trente ans.” Cité libre, 
June, 5-9.

—_. 1957. "Réflexions sur l'état de siege (de Jean Desprez à M. Duplessis)." Cité libre, February, 32-40.

Petrey, Sandy. 1988. Realism and Revolution: Balzac, Stendhal, Zola, and the Performances of History. Ithaca, NY: Cornell University Press.

Piotte, Jean-Marc. 1964. “Autocritique de Parti pris.” Parti pris, September, 36-44.

Rioux, Marcel. 1955. "Idéologie et crise de conscience du Canada français.” Cité libre, December, 1-29.

Sontag, Susan. 1978. Illness as Metaphor. New York: Vintage—Random.

Tremblay, Jacques. 1961. “Je voudrais parler à un homme.” Cité libre, May, 5-11.

Trudeau, Pierre Elliott. 1961. “L’Aliénation nationaliste.” Cité libre, March, 3-5

—_. 1962. "La nouvelle trahison des clercs.” Cité libre, April, 3-16.

Vadeboncoeur, Pierre. 1952. "Pour une dynamique de l’action.” Cité libre, June-July, 11-30.

—_. 1953. "Critique de notes psychologie du peuple.” Cité libre, November, 11-28.

\footnotetext{
${ }^{1}$ Dion's study in particular, Les intellectuels et le temps de Duplessis, gives a broad view of who the Citélibristes were and explores their role in Quebecois society, both at the time of the journal's publication and once the contributors gave up their positions at Cité libre.

${ }^{2}$ For the implications of this rhetoric in different contexts, see Damien-Claude Bélanger, "L'Antiamericanisme et l'antimodernisme dans le discours de la droite intellectuelle du Canada, 1891-1945,”(2008) and Sylvie Beaudreau, "Déconstruire le rêve de nation: Lionel Groulx et la Révolution tranquille" (2002).

${ }^{3}$ Subsequent political appropriations of medical discourse, for instance in Parti pris, will draw much more heavily on the rhetoric of psychology than Cité libre, likely owing to the writers' interest in and alignment with the decolonization movements, which were heavily influenced by the psychology-inflected anti-colonial writings of Frantz Fanon.

${ }^{4}$ In addition to the medicalized functions attributed to Cité libre in histories which have already been discussed, Bill Marshall, Ramsay Cook (2005), and Jocelyn Maclure (among many others) also use medical metaphors, in this case diagnosis, in their analyses of Quebec's political and cultural history.
} 
${ }^{5}$ That such critiques also contribute to the collective vision of the nation, while significant, is a matter that is best discussed elsewhere.

${ }^{6}$ In other contexts, such as nineteenth century France, literary texts are also often explicitly curative. See Caron (2001) on Zola’s Rougon-Maquart novels.

${ }^{7}$ Naturally when one considers a periodical like Cité libre, a measure of suppleness with regard to chronology is required, for authors are likely to favour certain turns of phrase or ideas and thus return to them. Likewise they may revisit ideas (theirs and others') after a number of years and pick up the same metaphors in their subsequent pieces. The periodization none the less reflects changes in the journal's use of medical rhetoric rather than a pure imposition of particular dates of political or social significance.

${ }^{8}$ The incorporation into the medical realm those behaviors which are socially problematic is a longstanding tradition arising from the desire to classify these conditions as pathological and thus in need of remedy. One need only think of the somatization of drunkenness as alcoholism to see that what Vadeboncoeur and and Hertel do with the "physicialization" of psychological tropes is not without precedent. By rendering psychological conditions as physical ailments or impairments, the authors lend a sense of legitimacy and urgency to their observations, for concerns of physical health are to this day popularly regarded as more "serious" than matters of mental health.

${ }^{9}$ Behiels argues that Pierre Vadeboncoeur was alone among Citélibristes in seeing that "nothing could be done to revive the dying corpse of French-Canadian culture." All others "believed in the possibility of a modern, secular, democratic, and pluralistic French-Canadian society emerging if the appropriate strategy of thought and action was undertaken” (1985, 89).

10 This new orientation in turn likely reflects the political events which took place in Quebec at the time, namely the 1956 election and the turbulent lead up to the 1960 election, which included the deaths of Maurice Duplessis and his successor Paul Sauvé. Behiels also notes the emergence of strong engines of neo-nationalist thought such as L'Action nationale and the new inflections of Le Devoir under Gérard Filion and André Laurendeau.

${ }^{11}$ I would argue that Jocelyn Létourneau's Passer à l'avenir: Histoire, mémoire, identité dans le Québec d'aujourd'hui (2000) performs a similar task for a new generation.

12 In 1963, two out of six total tropes were focused on treatment; by 1964 the ratio had increased still further to five out of twelve.

13 The discrepancy between the number of metaphors in the first ten years and the final six is largely made up of the tropes dealing with diagnosis and treatment.

14 The founding of Parti pris in 1963 by a group of 20-something writers (and to a lesser extent the rise of the FLQ) may have had some impact on Kempf's assessment, for both these groups 
embraced the language of psychology and did not hesitate to talk about the economic and cultural inferiority of French Canadians in very direct terms.

${ }^{15}$ Bouthillette writes of Quebec: "Sa survivance est donc issue de sa précarité. La survie canadienne-française s'inscrit dans un dialogue douloureux, tragique et possiblement mortel, entre les deux entités de notre identité collective” $(1962,12)$. 